\title{
APPLICATION OF GEOTHERMAL ENERGY IN AGRICULTURE: A REVIEW
}

\author{
Omenikolo, A.I. \\ Department of Physics/Electronics \\ Federal Polytechnic, Nekede, Owerri, Nigeria
}

\author{
Obasi, I. B. \\ Department of Physics/Electronics \\ Federal Polytechnic, Nekede, Owerri, Nigeria
}

\author{
Nleonu, E. C. \\ Department of Chemistry/Biochemistry \\ Federal Polytechnic, Nekede, Owerri, Nigeria
}

\begin{abstract}
Agriculture is one of the important sectors of any economy. It provides the main source of livelihoods for the majority of the citizen in most developing countries. However, the people in these countries face famine and poverty, mainly as a result of post-harvest losses and the lack of affordable energy for aquaculture and food processing. The lack of sustainable supply of energy is a major constraint to the development of this sector in developing countries. Geothermal energy has been utilized mainly to generate electricity; it can be harnessed for other important uses in agriculture. Developing countries endowed with this renewable energy source have ample potential to use it in advancing their agricultural sector. This paper reviews the application of direct use of geothermal energy in agriculture, geothermal resources, the advantages, constraints and challenges of geothermal energy. The environmental impacts associated with geothermal energy utilization, current mitigation control methods were discussed.
\end{abstract}

Keywords: geothermal energy, environmental impacts, agriculture, greenhouse, power plants.

\section{INTRODUCTION}

The demand for energy is continuously increasing as a result of growth in population, urbanization and industrialization. Presently the utilization of fossil energy resources creates increasingly disastrous effects on the global environment (Sun et al., 2003; 2009). In view of this, there is an urgent need to develop sustainable and new energy saving technologies and secure new renewable energy sources that can substitute for fossil fuels. An important contribution could be made by rapidly expanding the use of renewable energy sources, such as geothermal energy (Hepbasli, 2003; Balat, 2005; Konak and Pamukcu, 2006; Kirtay, 2010). Geothermal energy, one of the most promising among renewable energy sources, has proven to be reliable, clean, and safe, and therefore, its use for power production, heating and cooling is increasing. The use and study of geothermal energy has been greatly improved in the 1990's for supplying reusable energy for the increased worldwide energy demand (Dickson and Fanelli, 2004). One of its biggest advantages is that it is constantly available. The constant flow of heat from the Earth ensures an inexhaustible and essentially limitless supply of energy for billions of years to come. Radioactive elements within the earth release heat at very high temperatures, which increase depending on the distance from the earth's surface (Figure 1). The temperature of the earth's core is estimated to be about $5000{ }^{\circ} \mathrm{C}$, and the outer core is about $4000{ }^{\circ} \mathrm{C}-\mathrm{a}$ similar temperature to that on the surface of the sun (Figure 1). The constant flow of heat energy from the earth's interior, equivalent to an estimated 42 million megawatts (MW) of power, is expected to continue for billions of years (Íslandsbanki, 2011).

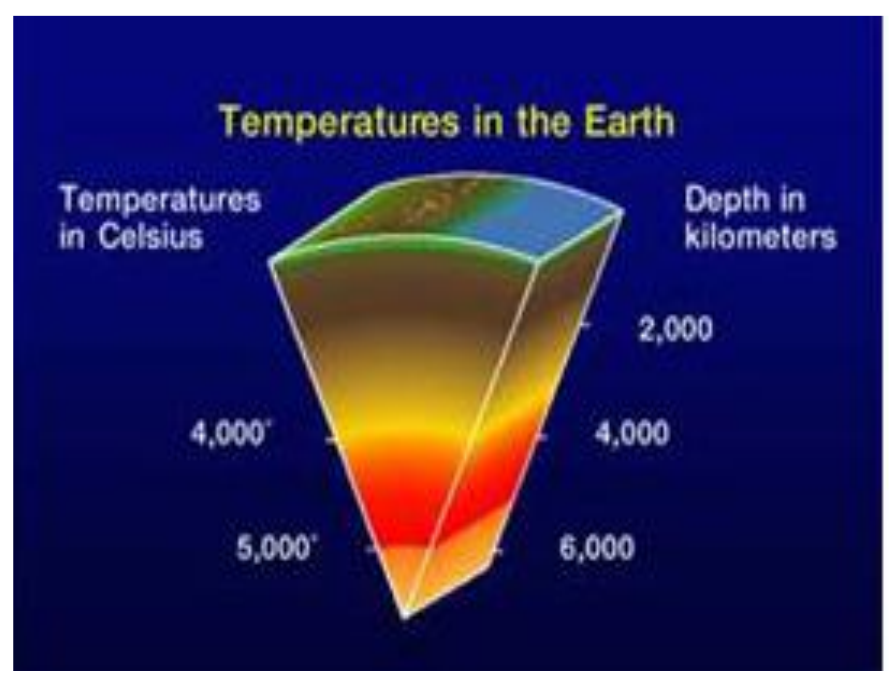

Figure1. Temperatures in the earth (from Energy and Geosc. Inst. 1997).

\section{A) Geothermal resources}

Geothermal resources are commonly divided into four categories: hydrothermal, hot dry rock, magma, and geopressured.

I) Hydrothermal

Hydrothermal systems are associated with recent volcanic activity and are found near plate tectonic boundaries (subduction, rifting, spreading or transform faulting), or at crustal and mantle hot spot anomalies. They are typically located at depths of $1-4 \mathrm{~km}$ and contain steam or liquid water 
up to $3500 \mathrm{C}$ in a convectively active, permeable region of porous rock. Liquid dominated systems have been used for centuries and are still the most widely exploited globally. The commonest application has been for thermal baths and therapeutic spas; more recently hot water has been widely used for space heating (in Iceland), for agriculture (greenhouses, seed beds), fish farming and chemical manufacture, either as a source of minerals (borax, potash, etc.). The highest grade, vapor dominated systems occur rarely, are primarily of interest for electricity generation. Examples are the Larderello field in Italy, The Geysers field in California, and the Matsukawa field in Japan.

\section{II) Hot dry rock}

This has been used to describe geothermal systems where fluids are not produced spontaneously. In many situations, these are really non-productive hydrothermal systems that require stimulation before energy extraction can be achieved at economically viable rates. Such systems can occur within or at the margins of an active hydrothermal reservoir system or, at another extreme, may be associated only with above-average heat flow in a conduction-dominated geologic setting. In principle, hot dry rock systems are available everywhere just by drilling sufficiently deep to produce rock temperature useful for heat extraction usually taken to be greater than $1500 \mathrm{C}$ for producing electricity and greater than $50-1000 \mathrm{C}$ for direct heat use.

\section{III) Magma}

Magma resources consist of partially or completely molten rock encountered at accessible depths of less than $7 \mathrm{~km}$ in regions of recent volcanic activities. Magma typically emits mineralized liquids and gases, which then mix with deeply circulating groundwater. Such systems can last hundreds of thousands of years, and the gradually cooling magmatic heat sources can be replenished periodically with fresh intrusions from a deeper magma chamber. Magma's very high temperatures, in excess of $6500 \mathrm{C}$, make it particularly attractive for efficient electric power production or for high temperature industrial process heat applications. Heat energy is also transferred by conduction, but convection is the most important process in magmatic systems.

\section{IV) Geopressured}

Geopressured systems are characteristically found in large sedimentary basins at depths of $3-7 \mathrm{~km}$. The geopressured reservoirs consist of permeable sedimentary rocks, embedded within impermeable low-conductivity strata, containing pressurized hot water that remained trapped at the moment of deposition of the sediments. The hot water pressure approaches lithostatic pressure, greatly exceeding the hydrostatic pressure. The geopressured reservoirs can also contain significant amounts of methane. The geopressured systems could produce thermal and hydraulic energy (pressurized hot water) and methane gas. A typical geopressured system is found in the Northern Gulf of Mexico Basin in the USA, both offshore and onshore. Figure 2 is a simple representation of an ideal geothermal system.

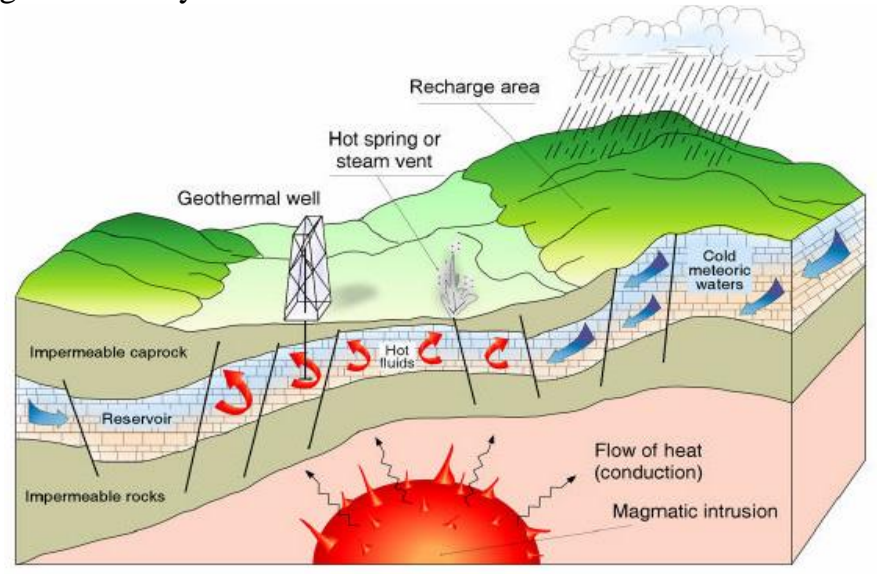

Figure 2. Simple representation of an ideal geothermal system(Dickson and Fanelli, 2004)

\section{B. Types of power plants \\ I) flash steam power plant}

Flash steam power plants (Figure 3) are the most common type of geothermal power plant. The steam, once it has been separated from the water, is piped to the powerhouse where it is used to drive the steam turbine. The steam is condensed after leaving the turbine, creating a partial vacuum and thereby maximizing the power generated by the turbine-generator. The steam is usually condensed either in a direct contact condenser, or a heat exchanger type condenser.

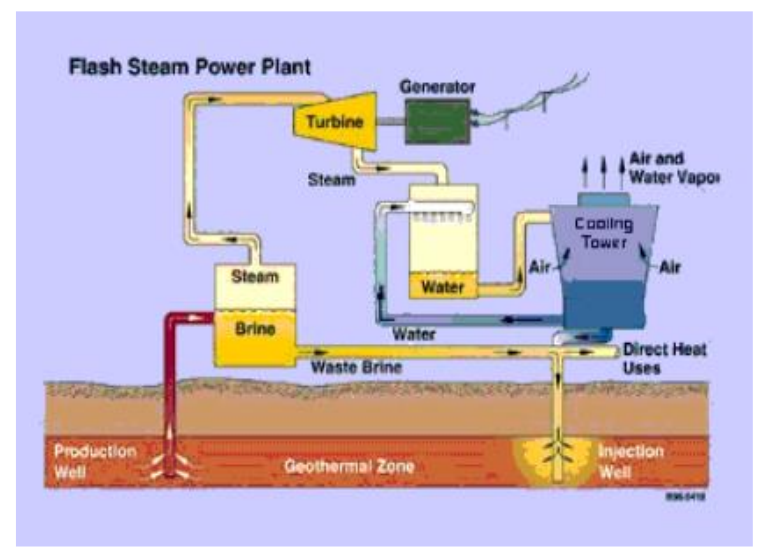

Figure 3. Flash steam power plant

Dry steam power plants

Power plants using dry steam systems were the first type of geothermal power generation plants built. They use steam from the geothermal reservoir as it comes from wells and route it 
directly through turbine/generator units to produce electricity (Figure 4). Geysers are the main source of dry steam.

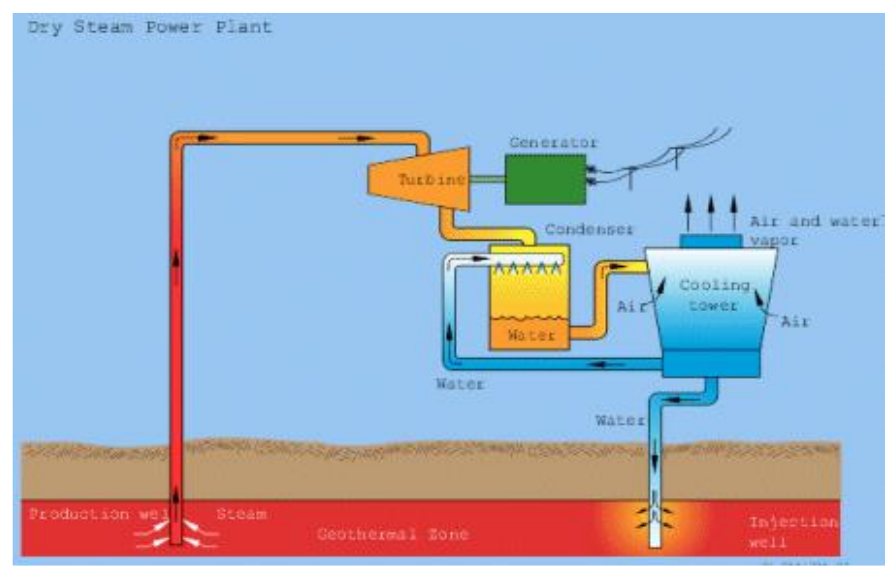

Figure 4. Dry steam power plant.

III) Binary power plant

In this type, geothermal water is passed through a heat exchanger where its heat is transferred to a secondary liquid. Liquids having lower boiling point are used as secondary liquid such as isobutene, isopentane or ammonia-water mixture. The vapour of secondary liquid are used to rotate turbines. The binary system is useful in geothermal reservoirs which are relatively low in temperature. Heat loss is minimum as system is completely closed. Hot water is immediately recycled back into the reservoir. The working fluid is also condensed back to the liquid and used over and over again.

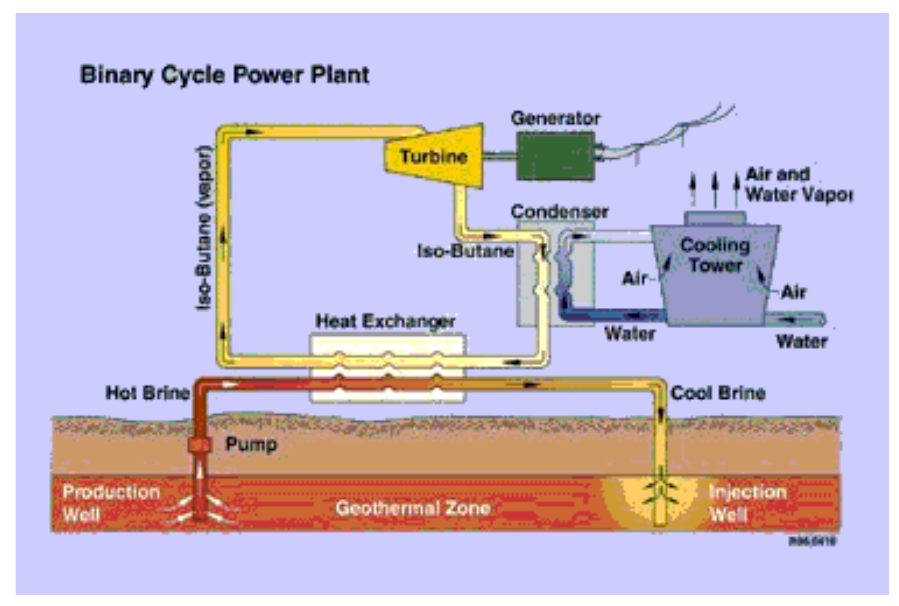

Figure 5. Binary cycle power plant

\section{IV) Flash/binary combined cycle}

This type of plant, which uses a combination of flash and binary technology, has been used effectively to take advantage of the benefits of both technologies. In this type of plant, the portion of the geothermal water which flashes to steam under reduced pressure is first converted to electricity with a back pressure steam turbine and the low-pressure steam exiting the back pressure turbine is condensed in a binary system.

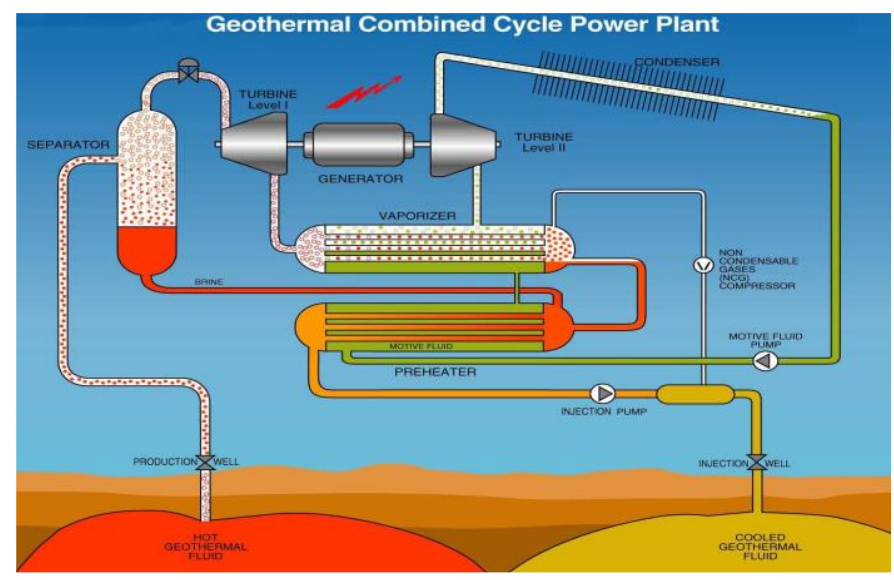

Figure 6. Flash/Binary Power Plant

\section{GEOTHERMAL APPLICATION IN AGRICULTURE}

Geothermal energy can be used directly, i.e. without any further conversion, as heat. The direct application of geothermal heat is referred to as direct use. Alternatively, geothermal heat can be converted into other types of energy at the expense of some energy for the conversion. Electric power generation requires conversion into electricity. Direct use exploits the resource more efficiently than power generation as no energy is lost during conversion of heat into electricity.

The different applications for direct-use of geothermal energy vary according to temperature. Direct use is typically associated with lower-temperature geothermal resources (those with temperatures less than $150^{\circ} \mathrm{C}$ ), though some applications may require higher temperatures. Geothermal heat could be used in agriculture for greenhouse heating or crop drying as well as in aquaculture and space heating. It could also be used for industrial processes such as concrete curing, milk pasteurization, chemical extraction, and refrigeration, drying organic materials (seaweed, grass etc), desalination, wool processing and pre-heating of water in coal-fired power stations. There are economic, environmental and energy efficiency benefits associated with the direct use of geothermal energy, including:

- Lower heating costs by reducing electricity, oil or gas consumption;

- $\quad$ Reduced emissions of $\mathrm{CO}_{2}$ and oxides of nitrogen and sulphur, by reducing consumption of fossil-fuelgenerated electricity; 
- Better use of resources, with reduced consumption of a high-grade fuel (such as natural gas) for low-grade heating; and,

- Minimal ongoing costs after installation.

In addition, at the lowest end of the temperature spectrum, ground source heat pumps can be used almost anywhere in the world to provide heating and cooling for buildings (Fridleifsson, 2001).

\section{A. Heating of greenhouses}

Geothermal energy has been used most extensively in agriculture for greenhouse heating during the last 25 years. Heating of greenhouses is one of the most common direct applications of geothermal energy which also controls the climate, predominantly relative humidity and temperature. Greenhouse heating is employed to grow crops such as vegetables and fruit in addition to flowers, houseplants and tree seedlings. The optimum temperature needed for growing different vegetables (Figure 6) and plants are different. Therefore depending upon the heating demand of green houses the temperature of water supplied ranges from 40- 1000C (Vasilevska, 2007).

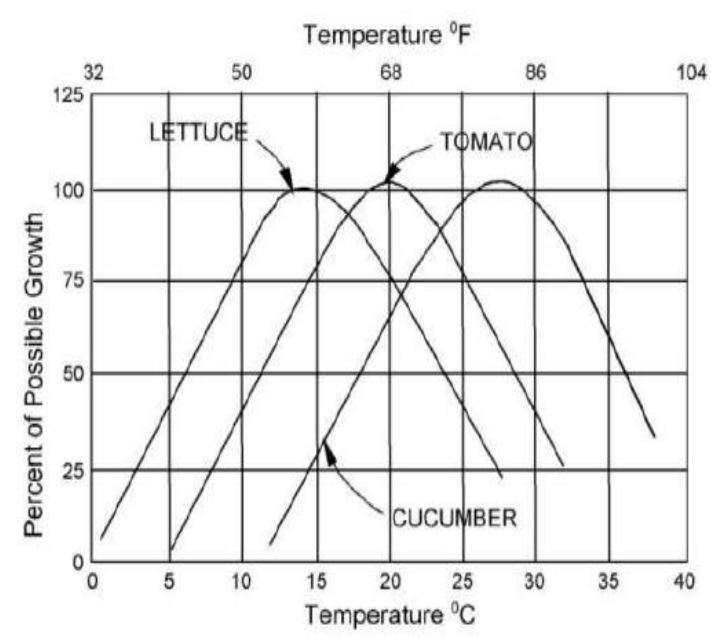

Figure 7: Optimum temperature for growing various vegetables (From Beall and Samuels, 1971)

\section{B. Aquaculture}

Aquaculture involves the raising of freshwater or marine organisms in a controlled environment to enhance production rates. The principal species that are typically raised are aquatic animals such as carp, catfish, bass, tilapia, frogs, mullet, eels, salmon, sturgeon, shrimp, lobster, crayfish, crabs, oysters, clams, scallops, mussels, and abalone.
The use of geothermal energy for aquaculture rather than water dependent upon the sun for its heat has demonstrated that more fish can be produced in a shorter period of time. When the water temperature is below the optimal range, the fish loses its ability to feed because the basic body metabolism is affected (Johnson, 1981). Thus a good geothermal supply, due to its constant temperature, can "out-perform" a natural mild climate.

\section{Crop drying}

The Geothermal energy has been applied in drying of vegetables, fruits crops and other cereals (Lund et. al., 2005). To avoid wastage and ensuring the availability of nutritious food all around the year the drying of agricultural products plays a very important role. The highest potential of geothermal resources for the purpose of agricultural drying applications includes low- to - medium enthalpy geothermal resources having temperature less than $150^{\circ} \mathrm{C}$. By recovering the waste heat from the geothermal power plant the heat required for drying can be obtained from the hot water or steam of geothermal wells. Rather than using the fossil fuel and electricity for food processing the geothermal energy is the most advantageous technique for agricultural processing including the far low costs of using hot water and steam.

\section{Milk pasteurization}

Dairy processing is yet another application of geothermal energy where fresh milk from the farmers can be pasteurized using hot geothermal water. A series of plate heat exchangers are used to keep the milk and heating water separated during pasteurization. Concentration of milk, one of the stages in milk powder production, requires temperatures below $100^{\circ} \mathrm{C}$. This is done in a falling film evaporator and the evaporation temperature can easily be obtained from geothermal water.

\section{E. Balneological and antibacterial uses}

Balneology is a medical practice of soothing aching muscles practiced in hot springs and health spas. The hot water from geothermal power stations is similar in chemistry to what is obtained from hotsprings. It can therefore be used in treatment of skin diseases as well as aching muscles. This wouldoffer semi medical treatment facilities for skin diseases. Health spas are good for recreation. InIceland, for example, the Blue Lagoon at Svartsengi power plant is one of the most visited attractionsin Iceland. The steamy waters are part of a lava formation, just like the geothermal waters at Olkaria.

\section{F. Geothermal district heating and cooling}

Geothermal district heating $(\mathrm{GDH})$ is the use of geothermal energy to provide heat to buildings and industry through a distribution network. Geothermal energy can be utilized for space heating and cooling, domestic hot water supply, and industrial Process heat requirements by district heating using 
peaking stations, a distribution system, central pumping stations, and in-building equipment (heat exchangers, circulation pumps, etc.). Space heating contains almost $88 \%$ of annual energy use in direct utilization (for 28 countries). China leads the GDH applications, followed by Iceland and Turkey. Considering their populations, Iceland leads the world in GDH applications per capita, and Turkey leads the individual space heating applications.

\section{G. Open field agriculture}

Geothermal water can be used to keep the soil in open fields at a steady warm temperature.Farmers run irrigation pipes under the soil to provide both water and heat to the crops.Using geothermal water for irrigation extends the growing season and keeps plants from being damaged by low air temperatures. Geothermal water can also sterilize soil to kill pests, fungus, and diseases that can harm crops. Sterilization requires very hot water so that the steam can be applied directly to the soil. The farmers either heat the soil from pipes underneath it, or they apply the steam above the soil and cover it with a plastic sheet to keep the heat inside.

\section{ADVANTAGES OF GEOTHERMAL ENERGY}

1) It is a renewable source of energy.

2) Geothermal energy is a renewable energy source that's highly environmentally friendly.

3) There is no wastage or generation of by-products.

4) Geothermal energy can be used directly. In ancient times, people used this source of energy for heating homes, cooking, etc.

5) Maintenance cost of geothermal power plants is very less compared to fossil-fired power generation plants on the same capacity.

6) Geothermal power plants don't occupy too much space and thus help in protecting natural environment.

7) Geothermal energy systems are adaptable to many different conditions. They can be used to heat, cool, or power individual homes, whole districts, or industrial processes.

8) Dependence on fossil fuels decreases with the increase in the use of geothermal energy. With the sky-rocketing prices of oil, many countries are pushing companies to adopt these clean sources of energy. Burning of fossil fuels releases greenhouse gases which are responsible for global warming.

9) Unlike other renewable energy sources, geothermal systems do not depend on the weather conditions. They can work in the summer or winter, and are not dependent on changing factors such as the presence of wind or sun. Geothermal power plants produce electricity or heat 24 hours a day, 7 days a week.

10) Job Creation and Economic Benefits: Government of various countries are investing hugely in creation of geothermal energy which on other hand has created more jobs for the populace.

\section{A. Constraints and challenges}

The main constraints and challenges to the use of geothermal energy in the agriculturaland food industries of developing countries are: i) policy and regulatory barriers; ii) technical barriers; and iii) financial barriers.

\section{I) Policy and regulatory barriers}

Government policies and legislation are important factors in creating an enabling environment for geothermal investment and resource mobilization and in encouraging investments from the domestic and foreign private sector. However, few governments have clear policies that promote the use of geothermal energy, and budgetary allocations to geothermal energy research and development tend to be low in developing countries. Most developing countries lack the financial resources to make the necessary investments in geothermal exploration and utilization. The legislative framework is inadequate for attracting private or foreign investment in geothermal projects. Governments can play a very important role in initiating geothermal projects by financing the early phases (i.e., exploration and appraisal). However, this requires the right policy environment, which is lacking in most cases. A successful geothermal system requires the right institutional framework, and coordination and consultation among relevant stakeholders. These are lacking in most developing countries, preventing the development of synergies and complementarily.

\section{II) Technical barriers}

Technical expertise is crucial for developing geothermal systems. A critical mass of policy analysts, economic managers, engineers and other professionals is required. However, there is a continuing shortage of qualified personnel in most developing countries. Infrastructure to support geothermal systems is often lacking or inadequate, including transport systems and communication networks.

\section{III) Financial barriers}

The high cost of geothermal energy technologies is one of the main barriers to geothermal energy development. It is that most developing countries lack the financial resources to enable investments in the development of geothermal systems. The shortage of funding for certain phases of geothermal energy deployment discourages investors from undertaking the crucial first steps, such as energy resource assessments or feasibility studies for geothermal energy projects. The limited availability of public funds often leads to competition for financial resources among different sectors, which may restrict the availability and allocation of funds to the geothermal energy 
sector. Financing plays an important role in geothermal programmes. The challenge often faced in the financing of geothermal energy projects is in developing models that can provide technologies and services to consumers at affordable prices while ensuring that the industry remains sustainable.

\section{B. Environmental impacts of geothermal plants}

Specific environmental impacts associated with the development of geothermal sites and operations of plants are inevitable. However, under normal conditions they are generally confined to the nature of the geothermal resource, location, extent of human habitation and are of lesser impact than those of other electric power generation technologies, particularly those using carbon based fossil fuels and nuclear fuels. Advancements in geothermal energy technology have allowed for a better management and mitigation of its effects to the environment.

\section{Geologic impacts}

Slightly more frequent occurrence of localized microseismic activities, hydrothermal steam eruptions, and ground subsidence may be potentially influenced by geothermal power operation. Earthquakes are caused by the rupture of a body of rock which radiates seismic waves that shake the ground. Because geothermal operations usually take place in areas that are also tectonically active, it is often difficult to distinguish between geothermal-induced and naturally occurring events. However, studies have shown that those generated by geothermal projects are usually microseismic activities that are not felt by man (Kagel et al., 2005). Ground subsidence could be addressed by reinjection of geothermal separated waters to maintain the reservoir pressure. Bromley et al. (2015) prescribes injection management as an adaptive tool to limit or control induced stresses to mitigate this effect.

\section{Social impacts}

Social acceptance by host community is a prerequisite of a successful geothermal energy development. It is substantially reliant on the ability of the project developers to ensure the enhancement of the positive impacts, the prevention or minimization of the negative impacts and the creation of benefits and just compensation for resident communities (Rybach, 2010).For instance, creating job opportunities for the resident communities, payment of royalties for the use of the natural resources of an area, provision of sustainable power supply, improved standard of living and empowerment.

\section{E. Water quality}

The discharge of waste bore water or condensate from a geothermal field to a local river or stream will alter water chemistry, affecting both aquatic ecosystems and terrestrial communities using the water as a resource. Although the same contaminants are contained in the fluids of natural geothermal features, in such hot springs and pools contaminants are attenuated to a greater degree by precipitation in sinters or fixation in soils and sediments. Even if waste fluids are reinjected on the field, contaminants may still reach surface waters via the groundwater system. Contamination of groundwater can occur during re-injection of waste bore water or condensate, or seepage from holding ponds for drilling fluids and well discharge. Surface water can also be contaminated by chemical spills or leaks during power-plant operation. These are unpredictable, usually avoidable problems, but the environmental effects of drilling fluids, fuels, lubricants, biocides, anti-sealants and other specialist chemicals stored on site must be considered during an environmental impact assessment. Groundwater contamination can be avoided by casing re-injection wells through the groundwater aquifer, and by lining holding ponds to prevent unacceptable seepage rates. Contaminant concentrations in fluid discharges to surface waters can be predicted from the geochemistry of the reservoir, and knowledge of the operating procedures to be used during power generation. Environmental and human health impacts can be minimized by ensuring that receiving water concentrations will not exceed national or international guidelines for water quality.

\section{F. Air quality}

Geothermal power is often considered to be a 'clean' alternative to the use of fossil fuels, which release more carbon dioxide and sulfur gases into the air during power generation. Geothermal power generation can nevertheless affect air quality through the discharge of gaseous contaminants from wells (during drilling and testing), steam condensate pots, silencers, and most importantly, the gas exhausters of the power station. At vapourdominated fields, and fields in which all waste fluids are reinjected, gas and steam are likely to be the only significant routine discharges. The most important gaseous contaminants from an environmental perspective are: carbon dioxide (CO2: usually the major component), hydrogen sulfide (H2S), ammonia (NH3), mercury $(\mathrm{Hg})$, boric acid (H3BO3). The discharge may also contain hydrocarbons such as methane or ethane and radon, but these constituents are less likely to have a significant adverse effect on the local environment. Contaminant concentrations in steam will depend on reservoir geochemistry and the power generation conditions. Before a geothermal field is developed, potential contaminant concentrations in both gas and steam discharges can be predicted from reservoir chemistry and knowledge of the operating procedures to be used during power generation. There are computer models available that calculate equilibrium concentrations for all components of a geothermal fluid during steam separation or during condensation. Computer models can also be used to predict plume dispersion, and contaminant concentrations at various levels in the atmosphere, as a function of distance from the discharge point. 


\section{International Journal of Engineering Applied Sciences and Technology, 2020 \\ Vol. 5, Issue 1, ISSN No. 2455-2143, Pages 666-673 \\ Published Online May 2020 in IJEAST (http://www.ijeast.com)}

\section{G. Cultural impacts of geothermal projects}

The greatest predicament in terms of culture centers on the potential impacts of geothermalprojects to the known way of life of the host community. Issues such as encroachment to ancestral lands, desecration of ancestral sites, and limits to their ability to practice their traditional way of life (hunting and gathering, nomadic lifestyle, among others) may all contribute to strong resistance from the community to accept any developmental project in their area. For the interest of the indigenous people and the geothermal developer to coexist (De Jesus, 1995), the geothermal developer must be concerned with protecting the forest and mountain. They must do so to ensure the recharge of their water-based geothermal resource. If the geothermal developer will protect the forest, it will also protect the ancestral domain of the host community. The geothermal developers and the host community therefore can complement their efforts in protecting the area. It is important to add that this partnership is facilitated when there is trust and respect between the two parties.

\section{H. Solid wastes}

Solid wastes of geothermal operation in the form of cartons, scrap metals and pipes, plastics andOther domestic wastes come from rig operations, base camps, work areas and storage yards. There are recyclers for these non-toxic residuals. The solid wastes of concern are the sludge that soaks up minerals in the cooling tower as brine is commonly used as an alternative medium to avoid the use of precious freshwater. Sludge from the cooling tower basins may be encapsulated by cement and other materials to make them inert. Wastes can also be managed by chemically reducing solid wastes to soluble forms before reinjection. Biotechnology methods such as the use of bacteria can also dissolve, separate or immobilize hazardous geothermal sludge (Premuzik, 1989). There are also waste treaters accredited by environmental bodies to handle specific chemical pollutants. Some minerals may be recovered and recycled for industrial use.

\section{Noise}

A geothermal power plant may generate noise levels in the 71$83 \mathrm{~dB}$ range. Unwanted noise can be a nuisance or a health concern. Exposure for more than $8 \mathrm{~h}$ a day to sound in excess of $85 \mathrm{~dB}$ is potentially hazardous. The WHO guidelines for community noise state that levels should not exceed $55 \mathrm{~dB}$ for outdoor living areas and $70 \mathrm{~dB}$ for industrial areas (WHO, 1999). The different phases of geothermal development have different sources of noise. During exploration and drilling, noise sources include earth-moving equipment (related to road, well pad and sump pit construction), vehicle traffic, seismic surveys, blasting, and drill rig operations. Well drilling and testing activities are estimated to produce noise levels ranging from about 80 to $120 \mathrm{~dB}$ at the site boundary. During the operation phase, noise sources include the power plant (turbines, transformers, cooling tower fans, separators etc.). To reduce noise, the use of mufflers, temporary barriers, and natural topography may be necessary. Furthermore, because noise has been found to be a particularly irritating problem, it is extremely important to conduct noisy drilling and construction operations during the least sensitive times of the day and to keep local regulators and neighbors informed about project activities.

\section{CONCLUSION}

Geothermal energy is no doubt a valuable resource. It is relatively clean and environmentally friendly when compared to present energy sources such as fossil fuels. Geothermal energy also has a promising future as costs for natural gas and coal escalate, resources become diminished, and regulatory agencies continue to limit what fuel-burning companies can release to the atmosphere. has the potential to provide long-term and secure base-load energy for the agricultural and food industries. Geothermal energy is already used in these industries in many countries, but geothermal development has been slow in most. The main constraints and challenges impeding the use of geothermal energy in the agricultural and food industries are policy, regulatory, technical and financial barriers. Governments of developing countries have to take into consideration these constraints and challenges. Once the constraints have been addressed, a moderate increase in direct utilization can be expected in the future. Geothermal energy has both the technical and economic potential to facilitate the development of a range of added-value agricultural products.

\section{REFERENCES}

[1] Balat, M., (2005). Recent status of geothermal energy applications in Turkey. Energy Exploration \& Exploitation 23(1), (pp. 41-50).

[2] Beall, S. E., \& Samuels, G. (1971). Use of warm water for heating and cooling plant and animal enclosures (No. ORNL-TM-3381). Oak Ridge National Lab., Tenn..

[3] Berglund, B., Lindvall, T., Schwela, D. H., \& World Health Organization. (1999). Guidelines for community noise.

[4] Bromley, C. J., Currie, S., Jolly, S., \& Mannington, W. (2015, April). Subsidence: an update on New Zealand geothermal deformation observations and mechanisms. In World Geothermal Congress (Vol. 1, pp. 19-25).

[5] De Jesus, A. C., (2005). Environmental benefits and challenges associated with geothermal power Generation. (pp. 1-38).

[6] Dickson, M. H., \&Fanelli, M. (2002). What is geothermal energy. Istituto di Geoscienze e Georisorse, CNR, Pisa, Italy, 


\section{International Journal of Engineering Applied Sciences and Technology, 2020 \\ Vol. 5, Issue 1, ISSN No. 2455-2143, Pages 666-673 \\ Published Online May 2020 in IJEAST (http://www.ijeast.com)}

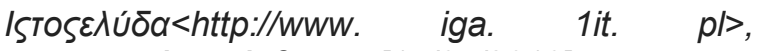

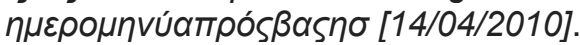

[7] Molarty, L., \& Reed, M. J. (1992). The US geothermal industry. Energy Sources, 14(4), (pp. 443-456).

[8] Fridleifsson, I. B. (2001). Geothermal energy for the benefit of the people. Renewable and sustainable energy reviews, 5(3), (pp. 299-312).

[9] Hepbasli, A. (2003). Current status of geothermal energy applications in Turkey. Energy Sources, 25(7), (pp. 667-677).

[10] Íslandsbanki, R., (2011). U.S. geothermal industry overview. Geothermal Research.

[11]Johnson, W.C., (1981). "The Use of Geothermal Energy for Aquaculture," Proceedings, The First Sino/U.S. Geothermal Resources Conference (Tianjin, PRC), Geo-Heat Center, Klamath Falls, Oregon.

[12] Kagel, A., Bates, D., \&Gawell, K., (2005). A guide to geothermal energy and the environment, Washington. Geothermal Energy Association.

[13] Kirtay, E., (2010). Current status and future prospects of renewable energy use in Turkey. Energy Exploration and Exploitation 28(5), (pp. 411-432).

[14] Konak, G., \&Pamukcu, C., (2006). Geothermal energy-economy, potential and utilization possibilities in Turkey. Energy Exploration \& Exploitation 24(1-2), (pp. 271-283).

[15] Kristmannsdóttir, H. A. (2003). Environmental aspects of geothermal energy utilization. Geothermics. 32(4), (pp. 51-61).

[16]Lund, J.W., Freeston, D.H., \& Boyd, T.L., (2005). Direct application of geothermal energy: 2005 worldwide review. Geothermics . 34(6), (pp. 691727).

[17] Mock, J.E., Tester, J.W., \& Wright, P.M., (1997). Geothermal energy from the Earth: Its potential impact as an environmentally sustainable resource. Annual Review of Energy and the Environment, 22, (pp. 305-356).

[18]Premuzik, E., (1989). Advanced biochemical processes for geothermal brines. Annual Report, New York, Brookhaven National Laboratory.

[19] Rybach, L., (2010). Legal and regulatory environment favourable for geothermal development investors. In: Proceedings of the World Geothermal Congress, Bali, Indonesia.

[20] Sun, Y.Z., Zhang, H.J., Du, Z.C., Li, Q.X. \& Li, Z.X., (2003). Organic pollution of street dust in the Handan City, China. Bulletin of Environmental Contamination and Toxicology 70(3), (pp. 422-429).

[21]Sun, Y.Z., Fan, J.S., Qin, P., \&Niu, H.Y., (2009). Pollution extents of organic substances from a coal gangue dump of Jiulong Coal Mine, China. Environmental Geochemistry and Health 31, (pp. 8189).
[22] Vasilevska, S.P. (2007). Greenhouse heating systems. Research on the energy efficiency and availability of greenhouse climate conditioning systems. 59.

[23] Van Nguyen, M., Arason, S., Gissurarson, M., \&Pálsson, P. G. (2015). Uses of geothermal energy in food and agriculture. Opportunities for developing countries. 